\title{
Recovery of Essential Plant Nutrients from Biofuel Residual
}

\author{
S. Agyin-Birikorang ${ }^{1}$, G. A. O’Connor ${ }^{2}$, P. C. Pullammanappallil ${ }^{3}$, G. R. Mohan $^{3}$ \\ ${ }^{1}$ Research and Development Division, International Fertilizer Development Center, Muscle Shoals, USA \\ ${ }^{2}$ Soil and Water Science Department, University of Florida, Gainesville, USA \\ ${ }^{3}$ Agricultural and Biological Engineering Department, University of Florida, Gainesville, USA \\ Email: SAgyin-Birikorang@ifdc.org, gao@ufl.edu
}

Received January 16, 2013; revised February 16, 2013; accepted May 1, 2013

Copyright (C) 2013 S. Agyin-Birikorang et al. This is an open access article distributed under the Creative Commons Attribution License, which permits unrestricted use, distribution, and reproduction in any medium, provided the original work is properly cited.

\begin{abstract}
Essential plant nutrients contained in residues and wastes generated during biofuel processing can be recovered for further production of bioenergy biomass. The objective of this study was to determine the relative agronomic efficiency of "processed" biofuel residual (PBR). Liquid biofuel residual was "processed" by precipitating phosphate and ammonium in the residual with magnesium into a struvite-like material. Then, in a series of greenhouse experiments, we evaluated the fertility potential of PBR, using sweet sorghum (Sorghum bicolor (L.) Moench), as a test bioenergy crop. We compared the agronomic effectiveness of PBR to inorganic commercial fertilizers, biosolids, and poultry manure as nutrient sources. The sources were either applied alone or in combination with supplemental essential plant nutrients $(\mathrm{S}, \mathrm{K}, \mathrm{Mg}$, and micronutrients). In each of the greenhouse experiments, the crop was grown for $12 \mathrm{wk}$ on soil of minimal native fertility. After each harvest, sufficient water was applied to the soil in each pot over a 6 -wk period to yield $\sim 2 \mathrm{~L}$ ( $\sim$ one pore volume) of leachate to assess potential total $\mathrm{N}$ and soluble reactive phosphorus (SRP) losses. Dry matter yields from the PBR treatment applied alone were significantly greater than yields from inorganic fertilizers, biosolids, and poultry manure treatments applied alone, and similar to yields obtained when the supplemental essential plant nutrients were added to the inorganic fertilizer, biosolids, and manure treatments. Leachate $\mathrm{N}$ and SRP concentrations from the PBR treatment were significantly lower than in the treatments with inorganic fertilizers, poultry manure, and biosolids. We conclude that PBR can substitute for inorganic fertilizers and other organic sources of plant nutrients to produce bioenergy biomass cheaply, without causing offsite $\mathrm{N}$ and $\mathrm{P}$ losses in vulnerable soils.
\end{abstract}

Keywords: Bioenergy Biomass; Dry Matter Yield; Leaching N and P Losses; Processed Biofuel Residual (PBR); Sweet Sorghum

\section{Introduction}

Growing environmental and economic concerns over use of fossil fuels have prompted the search for alternative fuels, including biofuels such as ethanol. Ethanol is a renewable, environmental-friendly energy source produced through fermentation of the constituent sugars of biomass, and can either be used as mixtures with conventional gasoline fuels or as a sole fuel source [1]. In addition to being nontoxic, ethanol is biodegradable and essentially sulfur-free. Switching from fossil fuel to biofuel to power vehicular engines will reduce carcinogenic air toxics, carbon monoxide, and unburned hydrocarbons that contribute to smog and ozone formation [1]. Despite the ecological gains attributed to biofuel use, a major obstacle to its widespread use is the increased expense over conven- tional vehicular fuel [2]. Recycling the residues and wastes generated during biofuel processing for subsequent biomass production can potentially reduce the increased expense.

The biochemical platform for production of ethanol from cellulosic biomass typically involves thermal and/or chemical processing of the feedstock to convert the macromolecules to constituent sugars, followed by fermentation of the sugars to ethanol [3]. Both processes employ dilute or concentrated acids, particularly phosphoric acid, and later, ammonia at elevated temperatures to enhance the fermentation process [3]. The added phosphoric acids and/or ammonia, combined with $\mathrm{N}$ and $\mathrm{P}$ from the cellulosic biomass, accumulates in the biofuel residual [4]. The residual, thus, represents a potentially valuable nutrient source as well as a hazard if the nutrients escape to 
the environment, particularly to surface water bodies. The ever-increasing demand for biofuel in recent times, particularly in the developed countries, could lead to accumulation of large volumes of liquid biofuel wastes/ residuals in limited areas, which may eventually be discharged to landfill or surface water bodies. Biofuel residual discharges to natural waters could promote eutrophication problems due to the high $\mathrm{N}$ and $\mathrm{P}$ contents and consequences for aquatic life and water supplies for domestic and industrial uses.

One of the proposed solutions to the potential environmental problem associated with biofuel residual discharge is to recover nutrients from the residuals and utilize it to fertilize subsequent biomass production. The key feature of this recovery technique is the combined removal of ammonium $\left(\mathrm{NH}_{4}^{+}\right)$, phosphate $\left(\mathrm{PO}_{4}^{3-}\right)$ and magnesium $\left(\mathrm{Mg}^{2+}\right)$ from supersaturated biofuel residual. The resulting product is magnesium ammonium phosphate hexahydrate $\left(\mathrm{MgNH}_{4} \mathrm{PO}_{4} \cdot 6 \mathrm{H}_{2} \mathrm{O}\right)$, commonly known as struvite, which precipitates according to following reaction [5]:

$\mathrm{Mg}^{2+}+\mathrm{NH}_{4}^{+}+\mathrm{PO}_{4}^{3-}+6 \mathrm{H}_{2} \mathrm{O} \rightarrow \mathrm{MgNH}_{4} \mathrm{PO}_{4} \cdot 6 \mathrm{H}_{2} \mathrm{O} \downarrow$

Several studies have explored recovery of ammonium and/or phosphate as struvite from different wastewaters, including supernatant of anaerobically digested sludge [6], anaerobically pretreated domestic wastewater [7], landfill leachate [5], source-separated human urine [8], leather tanning wastewater [9], filtered pig manure wastewater [10], anaerobic swine lagoon liquid [11], and industrial wastewater [12].

The overall objective of this study was to assess the feasibility of using PBR as a cost-effective and environmentally benign nutrient source for bioenergy biomass production. Specific objectives were to 1) characterize PBR to determine its suitability as plant nutrient source, 2) evaluate agronomic effectiveness of PBR relative to inorganic fertilizers and other organic sources of plant nutrients (biosolids and manure), and 3) determine the potential offsite $\mathrm{N}$ and $\mathrm{P}$ losses when PBR is land applied.

\section{Materials and Methods}

\subsection{Collection and Processing of Biofuel Residual}

Raw biofuel residual was collected from an ethanol processing plant at the Agricultural and Biological Engineering Department of the University of Florida. Ethanol is produced in the facility through fermentation of various organic materials, including waste grass clippings, cellulosic biomass, and municipal waste. The biofuel residual ( $\sim 12 \%$ solids) contains high amount of suspended organic materials. Prior to processing, the $\mathrm{NH}_{4}^{+}$and
$\mathrm{PO}_{4}^{3-}$ contents of the raw biofuel residual were measured to determine the quantity of reactants required to produce struvite.

A detailed description of the processing of wastewater from organic residuals, e.g. poultry manure, into struvitelike materials is presented in Yetilmezsoy and SapciZengin [13]. Briefly, the biofuel residual processing plant utilized for the present study consists of a precipitation reactor with stainless steel pipes for influent and reactants and effluent discharges, and a peristaltic pump (Figure 1). The reactor is composed of two parts: the bottom part is the reaction zone, and the top part is a settling zone that prevents fine particles from being lost in the effluent [13]. The settling zone is located above the reaction zone, is cone-shaped with an angle of $45^{\circ}$ between the two zones, and is equipped with a baffle to guide the flow. The effluent flows out at the top of the settling zone over a weir (Figure 1).

The success of struvite precipitation depends on two main factors: the $\mathrm{Mg}^{2+}: \mathrm{NH}_{4}^{+}: \mathrm{PO}_{4}^{3-}$ ratio and the $\mathrm{pH}$ of the solution [6]. Struvite precipitates if the product of $\mathrm{Mg}^{2+}, \mathrm{NH}_{4}^{+}, \mathrm{PO}_{4}^{3-}$ activities exceeds the equilibrium ion-activity product [11] or the thermodynamic solubility product [13]. Although $\mathrm{H}^{+}$concentration does not directly enter the ion activity product equation,

$\mathrm{MgNH}_{4} \mathrm{PO}_{4} \cdot 6 \mathrm{H}_{2} \mathrm{O}$ precipitation is highly $\mathrm{pH}$ dependent because the activities of both $\mathrm{NH}_{4}^{+}$and $\mathrm{PO}_{4}^{3-}$ are $\mathrm{pH}$ dependent [11]. Nelson et al. [11] showed that struvite solubility decreases with increasing $\mathrm{pH}$. Gadekar and Pullammanapallil [4] suggested that an optimum $\mathrm{pH}$ of

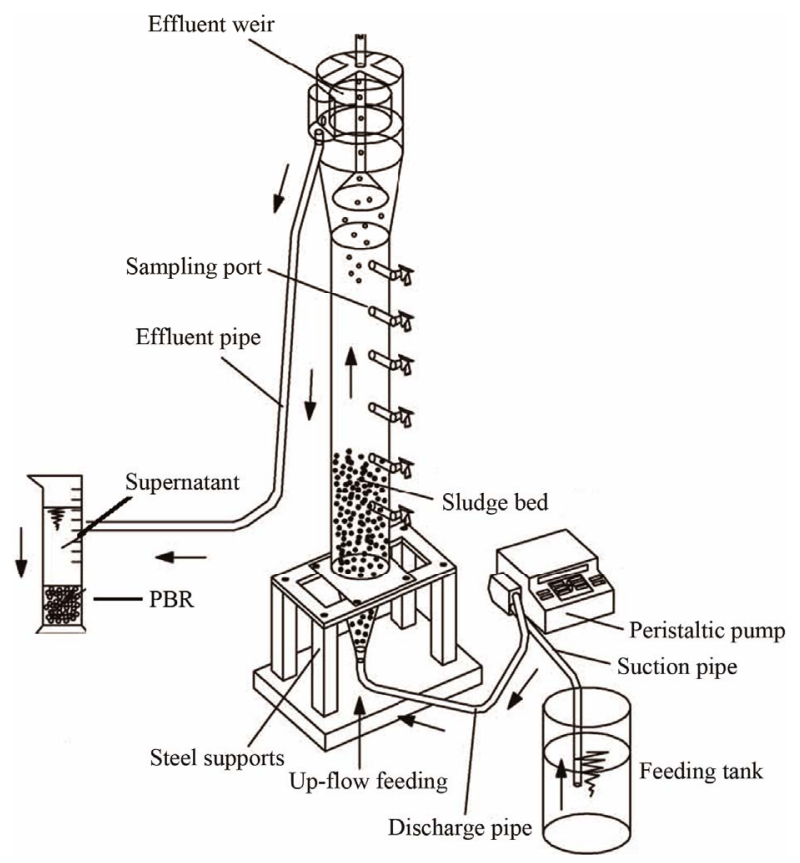

Figure 1. A schematic diagram of the reactor utilized for processing the biofuel residual (a modification of Yetilmezsoy and Sapci-Zengin [13]). 
the solution should be 9.0 to obtain a favorable struvite precipitation yield.

Raw biofuel residual was introduced into the reactor through injection tubes. Magnesium chloride

$\left(\mathrm{MgCl}_{2} \cdot 6 \mathrm{H}_{2} \mathrm{O}\right)$ solution $\left(720 \mathrm{mg} \mathrm{Mg} \cdot \mathrm{L}^{-1}\right.$, based on the result of chemical equilibrium model predictions [4]) was then added to provide the magnesium ions needed for the precipitation of $\mathrm{NH}_{4}^{+}$and $\mathrm{PO}_{4}^{3-}$ ions. The $\mathrm{pH}$ was adjusted to $\sim 9.0$ [4] with $0.1 \mathrm{M} \mathrm{NH}_{4} \mathrm{OH}$ through a membrane pump, and the suspension was agitated for $6 \mathrm{~h}$. All the runs were carried out at room temperature of $\sim 25^{\circ} \mathrm{C}$. The processed material was allowed to settle for $\sim 2 \mathrm{~h}$ to separate the precipitate from the bulk liquid.

Conventional struvite production from liquid wastes materials involves centrifugation to settle suspended materials, and the supernatant is used for the struvite production. The resultant struvite is generally white stable orthorhombic crystals [13]. In the present study, however, the supernatant was not separated from the suspended solids, and the resulting precipitated material includes organic matter and other constituents contained in the raw biofuel residual. Therefore, the precipitated material does not qualify as a pure struvite, but rather as a struvite-like material (referred throughout this paper as "processed" biofuel residual and abbreviated as PBR).

\subsection{Chemical Analyses to Characterize the "Processed" Biofuel Residual}

Extensive chemical analyses were conducted on the PBR to determine its agronomic potential, and possible environmental impact if the material is land-applied. Selected chemical characteristics of the raw biofuel residual and PBR are presented in Table 1. For total elemental analysis, subsamples of PBR were digested [14], and the digest was analyzed for the major plant nutrients including $\mathrm{P}, \mathrm{K}, \mathrm{Ca}, \mathrm{Mg}$ and $\mathrm{S}$; minor plant nutrients including $\mathrm{B}$, $\mathrm{Cu}, \mathrm{Fe}, \mathrm{Mn}, \mathrm{Mo}$, and $\mathrm{Zn}$. Digest was also analyzed for elements of environmental concerns including $\mathrm{Al}, \mathrm{As}, \mathrm{Cd}$, $\mathrm{Cr}, \mathrm{Pb}, \mathrm{Hg}$, and $\mathrm{Se}$. Mehlich-3 extractable $\mathrm{P}, \mathrm{K}, \mathrm{Ca}$, and $\mathrm{Mg}$ were determined using the procedure described in Mehlich [15] for the extraction, and the extracts were analyzed using inductively coupled plasma-atomic emission spectroscopy (ICP-AES) (PerkinElmer Plasma 3200; PerkinElmer, Wellesley, MA). Percent solids were determined by drying the material at $105^{\circ} \mathrm{C}$ [16], electrical conductivity (EC) and $\mathrm{pH}$ measurements were performed on the material as described by Thomas [17]. Total $\mathrm{N}$ concentration of the material was determined using the Kjeldahl procedure as described in Bremmer [18]. Inorganic $\mathrm{N}$ (ammonium and nitrate) was determined by the potassium chloride $(2 \mathrm{M} \mathrm{KCl})$ procedure [19], and Organic $\mathrm{N}$ content was calculated as a difference between total $\mathrm{N}$ and inorganic $\mathrm{N}$ content [20]. Sulfate $\left(\mathrm{SO}_{4}-\mathrm{S}\right)$ content was determined based on the method outlined in
Table 1. Selected chemical properties of the raw and the "processed" biofuel residual.

\begin{tabular}{|c|c|c|c|}
\hline Properties & Units & $\begin{array}{l}\text { Raw biofuel } \\
\text { residual }\end{array}$ & $\begin{array}{c}\text { "Processed" } \\
\text { biofuel residual }\end{array}$ \\
\hline $\mathrm{pH}$ & - & $7.46 \pm 0.15$ & $8.72 \pm 0.12$ \\
\hline $\mathrm{EC}$ & $\mathrm{dS} \cdot \mathrm{m}^{-1}$ & $1.24 \pm 0.09$ & $1.13 \pm 0.14$ \\
\hline Solids & \multirow{13}{*}{$\frac{T_{00}}{T_{0}}$} & $125 \pm 12.3$ & $281 \pm 31.4$ \\
\hline Organic carbon & & $418 \pm 44.1$ & $420 \pm 39.4$ \\
\hline Total phosphorus & & $35.2 \pm 3.43$ & $34.9 \pm 1.84$ \\
\hline Total nitrogen & & $65.8 \pm 5.68$ & $69.2 \pm 7.24$ \\
\hline Ammonium-nitrogen & & $23.6 \pm 3.01$ & $25.2 \pm 3.14$ \\
\hline Nitrate-nitrogen & & $33.6 \pm 3.64$ & $35.3 \pm 4.06$ \\
\hline Organic nitrogen & & $10.1 \pm 0.94$ & $9.74 \pm 1.02$ \\
\hline Sulfate & & $0.10 \pm 0.00$ & $0.11 \pm 0.02$ \\
\hline $\begin{array}{c}\text { Water extractable } \\
\text { phosphorus (WEP) }\end{array}$ & & $6.42 \pm 0.79$ & $0.29 \pm 0.04$ \\
\hline $\begin{array}{l}\text { Mehlich-3 extractable } \\
\text { phosphorus }\end{array}$ & & $18.4 \pm 2.04$ & $18.2 \pm 1.98$ \\
\hline $\begin{array}{l}\text { Mehlich-3 extractable } \\
\text { potassium }\end{array}$ & & $4.63 \pm 0.61$ & $4.58 \pm 0.62$ \\
\hline $\begin{array}{l}\text { Mehlich-3 extractable } \\
\text { calcium }\end{array}$ & & $1.02 \pm 0.03$ & $0.96 \pm 0.04$ \\
\hline $\begin{array}{l}\text { Mehlich-3 extractable } \\
\text { magnesium }\end{array}$ & & $0.94 \pm 0.17$ & $8.98 \pm 1.02$ \\
\hline Mehlich-3 extractable iron & \multirow{6}{*}{$\begin{array}{l}T_{00} \\
\stackrel{0}{0} \\
\dot{b} \\
\vec{a}\end{array}$} & $16.2 \pm 2.25$ & $16.2 \pm 2.12$ \\
\hline $\begin{array}{l}\text { Mehlich-3 extractable } \\
\text { manganese }\end{array}$ & & $0.61 \pm 0.08$ & $0.58 \pm 0.06$ \\
\hline $\begin{array}{l}\text { Mehlich-3 extractable } \\
\text { cupper }\end{array}$ & & $0.11 \pm 0.02$ & $0.09 \pm 0.00$ \\
\hline Mehlich-3 extractable zinc & & $0.24 \pm 0.02$ & $0.25 \pm 0.03$ \\
\hline $\begin{array}{l}\text { Mehlich-3 extractable } \\
\text { boron }\end{array}$ & & $0.10 \pm 0.01$ & $0.09 \pm 0.00$ \\
\hline $\begin{array}{l}\text { Mehlich-3 extractable } \\
\text { molybdenum }\end{array}$ & & $0.60 \pm 0.01$ & $0.54 \pm 0.01$ \\
\hline Total arsenic & \multirow{5}{*}{$\begin{array}{l}T_{00} \\
\ddot{60} \\
\dot{600} \\
\end{array}$} & $40.7 \pm 5.21$ & $34.6 \pm 4.35$ \\
\hline Total cadmium & & $4.96 \pm 0.58$ & $3.32 \pm 0.41$ \\
\hline Total chromium & & $3.54 \pm 0.42$ & $3.36 \pm 0.39$ \\
\hline Total mercury & & $\mathrm{bdl}^{\mathrm{a}}$ & bdl \\
\hline Total lead & & bdl & bdl \\
\hline PWEP $^{b}$ & $\%$ & $25.4 \pm 3.62$ & $0.16 \pm 0.02$ \\
\hline
\end{tabular}

${ }^{\mathrm{a}}$ below detection limit $\left(0.1 \mu \mathrm{g} \cdot \mathrm{L}^{-1}\right)$; ${ }^{\mathrm{b}}$ percent water extractable phosphorus $=$ (WEP/total phosphorus) $\times 100$.

Beaton et al. [21]. Water extractable P (WEP) was determined following the procedure described in Brandt et al. [22].

\subsection{Greenhouse Evaluation of "Processed" Biofuel Residual}

\subsubsection{Soil and Nutrient Sources Used}

Immokalee fine sand (sandy, siliceous, hyperthermic Arenic Alaquods) was used for the study. Native Immo- 
kalee fine sand, not previously contaminated by manure depositions and having "very low" native fertility, was collected from uncultivated site at the University of Florida Research and Education Center in Immokalee, FL. Multiple random bulk samples were collected from the surface horizon $(0-20 \mathrm{~cm})$ and thoroughly mixed to yield a composite sample.

Five nutrient sources (PBR, two biosolids with contrasting phosphorus $(\mathrm{P})$ phytoavailabilities [Gainesville Regional Utility (GRU) - high P phytoavailability, and Milorganite biosolids - low P phytoavailability], poultry manure, and commercial fertilizers (urea + triple superphosphate) were used in the study. The GRU biosolids was produced through aerobic digestion, and was obtained from the water reclamation facilities of the Gainesville Regional Utilities (Gainesville, FL). Milorganite biosolids, obtained from Milwaukee Metropolitan Sewerage District, Milwaukee, WI, was generated from anaerobically digested material that was heat-dried and pelletized. The Milorganite biosolids is stabilized with iron salts to decrease P solubility of the biosolids. The poultry manure was obtained from an egg producing farm in Indiantown, FL. Previous work [23] characterized the P phytoavailability of each nutrient source other than PBR.

\subsubsection{Characterization of Soil and Nutrient Sources Used}

Soil samples were air-dried and passed through a $2 \mathrm{~mm}$ sieve before analyses. Particle size distribution of the samples was determined using the pipette method [24]. Soil $\mathrm{pH}$ was determined in a 1:2 soil:water ratio using a glass electrode [25]. Total $\mathrm{C}$ and $\mathrm{N}$ of soil samples were determined by combustion at $1010^{\circ} \mathrm{C}$ using a Carlo Erba NA-1500 CNS analyzer (NA-1500 CNS, Carlo Erba, Milan, Italy) as outlined in Nelson and Sommers [26]. Soil test $\mathrm{P}$ concentration was determined using the Mehlich-3 extraction protocol [15], and WEP was determined following the procedure of Kuo [27]. The biosolids and manure were analyzed for solids content, total $\mathrm{N}, \mathrm{SO}_{4}-\mathrm{S}$, Mehlich-3 extractable $\mathrm{P}, \mathrm{Ca}, \mathrm{Mg}$, and $\mathrm{K}$; total $\mathrm{P}$, and WEP concentrations as described above in Section 2.2. Selected properties of the soil and nutrient sources used are presented in Tables 2 and 3, respectively.

\subsubsection{Experimental Setup in the Greenhouse}

Three consecutive greenhouse experiments were conducted, using "fresh" soil + treatments at each cropping, to verify and confirm results for the agronomic evaluations of PBR. The studies were conducted in a greenhouse at University of Florida campus in Gainesville, FL. Greenhouse temperature was maintained at $27^{\circ} \mathrm{C}$ (day) and $17^{\circ} \mathrm{C}$ (night). The five nutrient sources were each mixed with $8 \mathrm{~kg}$ of the soil at a recommended $\mathrm{N}$ applica-
Table 2. Selected physicochemical properties of the immokalee fine sand utilized for the study. Numbers are mean values of six replicates \pm one standard deviation.

\begin{tabular}{|c|c|c|}
\hline Properties & Units & Value \\
\hline $\mathrm{pH}$ & - & $5.62 \pm 0.34$ \\
\hline Sand & \multirow{4}{*}{$\frac{T_{00}}{\ddot{0}}$} & $976 \pm 58.9$ \\
\hline silt & & $9.96 \pm 1.13$ \\
\hline Clay & & $14.2 \pm 1.26$ \\
\hline Total carbon & & $8.84 \pm 1.58$ \\
\hline Total nitrogen & \multirow{9}{*}{ 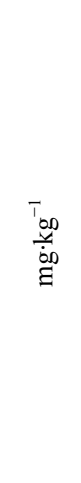 } & $1.47 \pm 0.16$ \\
\hline Nitrate-nitrogen & & $0.76 \pm 0.08$ \\
\hline Ammonium-nitrogen & & $0.42 \pm 0.07$ \\
\hline Total phosphorus & & $3.22 \pm 0.42$ \\
\hline Mehlich-3 extractable phosphorus & & $2.39 \pm 0.21$ \\
\hline Water extractable phosphorus (WEP) & & $1.16 \pm 0.18$ \\
\hline Oxalate extractable phosphorus & & $2.72 \pm 0.26$ \\
\hline Oxalate extractable aluminum & & $32.1 \pm 9.14$ \\
\hline Oxalate extractable iron & & $54.2 \pm 6.26$ \\
\hline $\mathrm{PSR}^{\mathrm{a}}$ & - & $0.04 \pm 0.01$ \\
\hline
\end{tabular}

${ }^{a}$ Phosphorus saturation ration $=$ oxalate extractable $\mathrm{P}(\mathrm{mmol}) /$ oxalate $\mathrm{ex}-$ tractable $\mathrm{Fe}+\mathrm{Al}(\mathrm{mmol})$.

Table 3. Selected chemical properties of the biosolids and manure used for the study. Numbers are mean values of six replicates \pm one standard deviation.

\begin{tabular}{|c|c|c|c|c|}
\hline Properties & Units & $\begin{array}{l}\text { Milorganite } \\
\text { biosolids }\end{array}$ & $\begin{array}{c}\text { GRU }^{\mathrm{a}} \\
\text { biosolids }\end{array}$ & $\begin{array}{l}\text { Poultry } \\
\text { manure }\end{array}$ \\
\hline $\mathrm{pH}$ & - & $6.36 \pm 0.21$ & $6.40 \pm 0.43$ & $6.82 \pm 0.24$ \\
\hline Solids & & $95.4 \pm 3.27$ & $5.45 \pm 0.92$ & $87.0 \pm 4.23$ \\
\hline Organic carbon & & $340 \pm 42.3$ & $362 \pm 39.8$ & $402 \pm 46.3$ \\
\hline Total phosphorus & & $21.5 \pm 2.34$ & $26.4 \pm 3.62$ & $18.9 \pm 3.85$ \\
\hline Total nitrogen & & $60.3 \pm 5.84$ & $62.6 \pm 7.13$ & $66.2 \pm 5.65$ \\
\hline Total iron & & $41.6 \pm 5.28$ & $7.70 \pm 0.83$ & $1.53 \pm 0.32$ \\
\hline Total aluminum & & $2.72 \pm 0.35$ & $5.52 \pm 0.46$ & $0.94 \pm 0.14$ \\
\hline $\begin{array}{l}\text { Water extractable } \\
\text { phosphorus (WEP) }\end{array}$ & $\begin{array}{l}T_{00} \\
\frac{y}{\dot{b}}\end{array}$ & $0.12 \pm 0.02$ & $6.91 \pm 0.84$ & $1.85 \pm 0.12$ \\
\hline $\begin{array}{c}\text { Mehlich-3 extractable } \\
\text { phosphorus }\end{array}$ & & $12.6 \pm 2.35$ & $22.8 \pm 3.14$ & $14.4 \pm 2.01$ \\
\hline $\begin{array}{l}\text { Mehlich-3 extractable } \\
\text { potassium }\end{array}$ & & $0.56 \pm 0.10$ & $1.24 \pm 0.19$ & $3.52 \pm 0.45$ \\
\hline $\begin{array}{l}\text { Mehlich-3 extractable } \\
\text { calcium }\end{array}$ & & $0.18 \pm 0.02$ & $0.22 \pm 0.03$ & $24.9 \pm 3.14$ \\
\hline $\begin{array}{l}\text { Mehlich-3 extractable } \\
\text { magnesium }\end{array}$ & & $0.11 \pm 0.04$ & $0.14 \pm 0.02$ & $5.28 \pm 0.72$ \\
\hline $\mathrm{PWEP}^{\mathrm{b}}$ & $\%$ & $0.58 \pm 0.12$ & $22.2 \pm 2.54$ & $9.78 \pm 1.01$ \\
\hline
\end{tabular}

${ }^{\mathrm{a}}$ Gainesville Regional Utilities; ${ }^{\mathrm{b}}$ percent water extractable phosphorus $=$ (WEP/total phosphorus) $\times 100$. 
tion rate of $150 \mathrm{~kg} \cdot \mathrm{PAN} \cdot \mathrm{ha}^{-1}$ for sweet sorghum [28]. The plant available N (PAN) was calculated based on the inorganic $\mathrm{N}$ content of the nutrient sources, and an assumed mineralization of the organic $\mathrm{N}$ content. Previous studies $[23,29]$ suggested $\sim 40 \%$ annual organic $\mathrm{N}$ mineralization from the manure and biosolids used for the study; therefore PAN for the nutrient sources was adjusted based on $40 \%$ organic $\mathrm{N}$ mineralization rate. The PBR-, manure-, and biosolids-amended soils were equilibrated ( $\sim 80 \%$ water holding capacity) in zip-lock plastic bags at room temperature for $2 \mathrm{wk}$ in the laboratory prior to use in the greenhouse. Chemical analyses of the PBR showed that the material contained adequate concentrations of $\mathrm{Mg}, \mathrm{K}, \mathrm{S}$, and micronutrients for crop growth so as a component of the study, we introduced a Sul-PoMag [a blend of sulfate, potassium and magnesium (18\% $\mathrm{S}, 22 \% \mathrm{~K}, 11 \% \mathrm{Mg})]$ and micronutrient treatments where the plants were either supplied with or without Sul-PoMag and micronutrients. A total of 24 treatment combinations were obtained [6 (5 nutrient sources + control $) \times$ 2 (with and without Sul-Po-Mag) $\times 2$ (with and without micronutrients)] and each treatment was randomly assigned to a pot. The pots were arranged in a randomized complete block design to minimize greenhouse positioning effects. Four replications for each treatment were used, yielding a total of 96 pots in each greenhouse experiment. The soil in each pot was wetted to, and maintained at $\sim 80 \%$ of the water holding capacity, and allowed to equilibrate for additional $1 \mathrm{wk}$ in the greenhouse before planting.

Sweet sorghum (Sorghum bicolor (L.) Moench), variety CSH-5 was selected as the test bioenergy crop and used in each greenhouse experiment. Studies have shown that sweet sorghum is a promising bioenergy crop, well adapted to several agro-ecosystems, and produces high bioenergy yields $[30,31]$. Six seeds of sweet sorghum were sown in each pot and misted daily to facilitate uniform germination. The inorganic $\mathrm{N}+\mathrm{P}$ fertilizer treatment was applied at the recommended rates of 150 $\mathrm{kg} \cdot \mathrm{N} \cdot \mathrm{ha}^{-1}$ and $55 \mathrm{~kg} \cdot \mathrm{P} \cdot \mathrm{ha}^{-1}$, respectively, at planting [28]. Five days after emergence, the seedlings were thinned to two plants in each pot, and the Sul-Po-Mag and micronutrient treatments were applied. Sul-Po-Mag solution was applied at $0.91 \mathrm{~g} \cdot \mathrm{pot}^{-1}$ to supply adequate and uniform $\mathrm{S}$, $\mathrm{K}$, and $\mathrm{Mg}$. Micronutrients were supplied using soluble trace element mix (The Scotts Company, Marysville, $\mathrm{OH}$ ) [a blend of boron, copper, iron, manganese, molybdenum and zinc $(1.35 \% \mathrm{~B}, 2.3 \% \mathrm{Cu}, 7.5 \% \mathrm{Fe}, 8 \%$ water soluble Mn, $0.04 \% \mathrm{Mo}, 4.5 \% \mathrm{Zn})]$ at $13.9 \mathrm{mg}$ pot $^{-1}$. The pots were weighed daily and the loss in weight was made up by adding distilled water to maintain $\sim 80 \%$ of the water holding capacity of the soil. The above-ground plant material of each pot was harvested at anthesis stage (12 wk after emergence) for yield determination and plant tissue analyses.

\subsubsection{Plant Tissue Analyses}

The fresh plant materials were placed in pre-weighed bags and dried at $60^{\circ} \mathrm{C}$ to a constant weight to represent dry matter yield (DMY). The dried samples were ground in a Wiley mill (Model 4 Thomas-Wiley Laboratory Mill, Thomas Scientific, Swedeboro, NJ) to pass a 1-mm screen for tissue analyses. For tissue $\mathrm{P}$ determination, the ground samples were digested as described by Andersen [14], and analyzed for P via the molybdenum blue method [32]. Tissue $\mathrm{N}$ concentration was determined using a micro-Kjeldahl method, a modification of the aluminum block digestion technique described by Gallaher et al. [33], followed by automated colorimetry with a Technicon Auto Analyzer. Phosphorus and N uptake were calculated as the product of DMY and tissue $\mathrm{P}$ or $\mathrm{N}$ concentration. The indices of relative agronomic effectiveness (RAE) were estimated based on DMY [34] as follows:

$$
\operatorname{RAE}(\%)=\left[\left(\mathrm{Y}_{1}-\mathrm{Y}_{0}\right) /\left(\mathrm{Y}_{2}-\mathrm{Y}_{0}\right)\right] \times 100
$$

where $\mathrm{Y}_{1}=\mathrm{DMY}$ from the nutrient sources applied alone, or in combination with Sul-Po-Mag and micronutrients, $\mathrm{Y}_{2}=$ DMY from treatment receiving the inorganic fertilizer supplied with Sul-Po-Mag and micronutrients, $\mathrm{Y}_{0}=$ DMY from the control.

\subsubsection{Post-Harvest Leaching and Leachate Analyses}

After harvest in each greenhouse experiment, sufficient deionized water (adjusted to $\mathrm{pH} 5.0$ ) was initially applied to each pot to yield $\sim 500 \mathrm{~mL}(\sim 0.25$ pore volume) of leachate. The soil was covered and allowed to equilibrate for $2 \mathrm{wk}$ and the leaching was repeated; followed by a third and fourth leaching each at $2 \mathrm{wk}$ intervals. Thus, a total of $\sim 2000 \mathrm{~mL}(\sim 1$ pore volume) leachate was collected over a period of $6 \mathrm{wk}$ after harvest to assess nutrient ( $\mathrm{N}$ and $\mathrm{P}$ ) losses. After each leaching event, the leachate collected was analyzed for SRP using the molybdenum blue method [32]. Leachate samples were also analyzed for $\mathrm{N}$ concentration using the USEPA Method 353.2 [35]. The product of the leachate volume and leachate $\mathrm{N}$ or $\mathrm{P}$ concentration yielded mass of $\mathrm{N}$ or $\mathrm{P}$ leached. Although leachates from the pots were not highly colored, total $\mathrm{P}$ was determined on the leachate to confirm that organic P loss from the pots was not significant. Since the $\mathrm{P}$ content of the various nutrient sources varied (Tables 1 and 3), P applied in the sources were not equal because application rate was based on $\mathrm{N}$ requirement of the crop (N-based rate), which also resulted in the applied $\mathrm{P}$ in all organic sources exceeding the recommended $\mathrm{P}$ rate. Therefore $\mathrm{P}$ leached was expressed as a percentage of $\mathrm{P}$ applied. 


\subsection{Statistical Analyses}

Differences in DMY, RAE, and $\mathrm{N}$ and P uptake among the treatments were statistically analyzed as a factorial experiment with a randomized complete block design, using the general linear model procedure (PROC GLM) of the SAS software [36]. Means of the various treatments were separated using a single degree of freedom orthogonal contrast procedure. The leachate $\mathrm{N}$ and $\mathrm{P}$ concentration data were not normally distributed (based on Kolmogorov-Smimov procedure and the normal probability plots [37]), and were normalized with a squareroot transformation before statistical analysis, based on the result of the Box-Cox transformation procedure [38]. The transformed data were then analyzed using the PROC GLM procedure. Means of the leachate N and P content resulting from the treatment were separated using a single degree of freedom orthogonal contrast on the transformed data. Data were back transformed for all discussions in the manuscript. Treatment differences were considered significant at $P \leq 0.05$.

\section{Results and Discussion}

\subsection{Chemical Characteristics of the "Processed" Biofuel Residual}

Selected chemical characteristics of the raw biofuel residual and PBR are presented in Table 1. The $\mathrm{pH}$ of the PBR was higher than the typical range of soil $\mathrm{pH}$ adequate for sorghum growth [28], but based on N-based application rates, quantities required for land application should not alter native soil $\mathrm{pH}$. Electrical conductivity of PBR was well below the reported critical EC value of 4 $\mathrm{dS} \cdot \mathrm{m}^{-1}$ associated with reduced plant growth caused by soil salinity [39]. Organic C content was much greater than typical soil organic $\mathrm{C}$ levels, and considerably greater than organic $\mathrm{C}$ levels of most biosolids produced and/or marketed in Florida [29]. The PBR contained high levels of plant available $\mathrm{N}\left(\mathrm{NH}_{4}-\mathrm{N}\right.$ and $\left.\mathrm{NO}_{3}-\mathrm{N}\right)$, which portends that application of PBR will immediately supply adequate quantities of $\mathrm{N}$ to the plant. Phosphorus concentrations of the raw biofuel residual and PBR were similar, and ranged from 32 to $36 \mathrm{~g} \cdot \mathrm{kg}^{-1}$, however WEP values of the raw biofuel residual $\left(\sim 6.4 \mathrm{~g} \cdot \mathrm{kg}^{-1}\right)$ was significantly greater than that of the PBR $\left(0.3 \mathrm{~g} \cdot \mathrm{kg}^{-1}\right)$. This suggests that $>95 \%$ of $\mathrm{P}$ precipitated out of the raw biofuel residual during processing into the struvite-like material. Several studies have demonstrated that WEP is a good measure of the environmentally relevant portion of $\mathrm{P}$ in soils and residuals, including manure and biosolids $[23,29,40]$. WEP is used to calculate percent water-extractable $P$ $(\mathrm{PWEP}=\mathrm{WEP} / \mathrm{TP} \times 100)$, which is a measure of the potential of $P$ sources to cause offsite runoff and leaching losses. Chinault and O'Connor [29] demonstrated that biosolids with PWEP values $\geq 10 \%$ has the potential to cause significant leaching losses in sandy soils with limited P sorption capacity. The PBR had PWEP values $\sim 0.16 \%$, below values observed from other studies [29] for most biosolids stabilized with $\mathrm{Fe}$ - and Al (PWEP $\sim 0.5 \%$ ) to reduce off-site $\mathrm{P}$ losses, and suggests that offsite $\mathrm{P}$ losses will be minimal when PBR is land-applied. The Mehlich-3 extractable $\mathrm{K}$ and $\mathrm{Mg}$, and sulfate $\left(\mathrm{SO}_{4}-\mathrm{S}\right)$ values suggest that the PBR could be a source of the three plant nutrients, in addition to $\mathrm{N}$ and $\mathrm{P}$. Furthermore, PBR also contained micronutrients (Fe, $\mathrm{Zn}, \mathrm{B}, \mathrm{Mo}$, etc.) essential for plant growth (Table 1). Total arsenic (As) concentrations for the PBR were below the residential direct exposure limit for As in Florida $\left(0.8 \mathrm{mg} \cdot \mathrm{kg}^{-1}\right.$ [41]), suggesting no threat for As contamination when PBR is land applied. Total $\mathrm{Cd}$ and $\mathrm{Cr}$ concentrations were well below the respective residential direct exposure limits, and also below the ranges of concentrations commonly found for soils in Florida and other states [41]. Total Pb and $\mathrm{Hg}$ concentrations were below the detection limits of the ICP-AES $\left(0.1 \mu \mathrm{g} \mathrm{L}^{-1}\right)$. The chemical characteristics of the PBR, thus, suggest that it could be an excellent nutrient source for plant growth, without causing adverse environmental impact if land applied.

\subsection{Properties of Soil, Manure, and Biosolids Used}

The soil was acidic (Table 2), but the $\mathrm{pH}$ was within the reported range of $\mathrm{pH}$ values $(5-7.5[28])$ deemed suitable for sweet sorghum production. The Mehlich-3 P and total $\mathrm{N}$ contents of the soil identify the soil as having "very low" native fertility [28], and requiring the maximum recommended rates of $\mathrm{N}$ and $\mathrm{P}$ to support normal growth and development of crops. The soil contained low total carbon and clay contents, which implies only a small capacity to retain cations. The coarse soil texture, with small clay and organic matter (Table 2) suggests that the soil could be highly susceptible to nutrient leaching losses. Intense rainfall or excessive irrigation combined with $\mathrm{N}$ and $\mathrm{P}$ application in such soil could enhance the potential risk of $\mathrm{N}$ and $\mathrm{P}$ leaching losses.

The two biosolids had total $\mathrm{N}$ and $\mathrm{P}$ concentrations (Table 3) typical of biosolids produced nationally in the USA [42]. Total concentrations of major elements (Al, $\mathrm{Fe}$, and $\mathrm{Ca}$ ) were also representative of biosolids produced nationally, and reflected individual wastewater and sludge treatment processes. O'Connor and Elliott [43] observed that $\mathrm{Fe}$ or $\mathrm{Al}$ concentrations of biosolids were generally $\leq 10 \mathrm{~g} \cdot \mathrm{kg}^{-1}$, unless chemicals were added to the waste stream for P removal (e.g., Milorganite biosolids). The manure and biosolids varied widely in the amount of labile P estimated as WEP. The Milorganite biosolids, stabilized with Fe salts, had low WEP values. The critical role of $\mathrm{Fe}$ and $\mathrm{Al}$ in determining $\mathrm{P}$ solubility and release from biosolids-amended soils is documented [44]. The 
GRU biosolids contained high PWEP values that exceeded the critical PWEP value of 10\% [29], and suggests that land application of the material could result in extensive $\mathrm{P}$ leaching in vulnerable soils. As expected, the poultry manure had high Ca content (Table 3) because $\mathrm{Ca}$ is a basic ingredient of poultry diet, and a representative PWEP value of $9.78 \%$.

\subsection{Sweet Sorghum Dry Matter Yield}

Nutrient application, in any form, enhanced biomass production of sweet sorghum, relative to yields obtained from the control treatment ( $\sim 25 \mathrm{~g} \cdot \operatorname{pot}^{-1}$; Figure 2). Sorghum yields were similar for respective treatments for the three growing seasons. Thus, there were no seasonal effects on DMY and yields were averaged across the three growing seasons and presented in Figure 2. The PBR was as effective as the other nutrient sources (inorganic fertilizer, manure, and biosolids) in enhancing biomass production of sweet sorghum, but was superior to the other nutrient sources when applied alone without addition of $\mathrm{S}, \mathrm{K}, \mathrm{Mg}$, and micronutrients (Figure 2). Thus, PBR applied alone is sufficient to supply the crop's nutrient needs and to completely substitute for fertilizer inputs. When the nutrient sources were applied alone, without addition of $\mathrm{S}, \mathrm{K}, \mathrm{Mg}$, and micronutrients, treatments with PBR produced the greatest DMY of $\sim 110$ $\mathrm{g} \cdot \operatorname{pot}^{-1}$, whereas yields from the nutrient source treatments occurring in the commercial fertilizer treatments were much lower $\left(\sim 70 \mathrm{~g} \cdot \operatorname{pot}^{-1}\right)$. Addition of $\mathrm{S}, \mathrm{K}$, and $\mathrm{Mg}$ (Sul-Po-Mag) to the nutrient sources significantly increased yields for the treatments with commercial fertilizers by $\sim 45 \%, \leq 40 \%$ for the two biosolids, and $\sim 30 \%$ for manure treatments. However, Sul-Po-Mag addition to the PBR did not significantly increase DMY, suggesting that the $\mathrm{S}, \mathrm{K}$, and $\mathrm{Mg}$ content of the PBR (Table 1) was adequate to supply those nutrients to meet the crop requirement when PBR was applied at N-based rates. Whereas addition of micronutrients resulted in further increases in DMY for the inorganic fertilizer treatment, DMY from the treatments with manure, biosolids, and PBR did not increase significantly over respective treatments having Sul-Po-Mag additions. This suggests that the manure, biosolids, and PBR could be applied without micronutrient addition when applied at N-based rates.

Relative agronomic effectiveness (RAE), as calculated with Equation (2), shows that PBR applied alone was $\sim 85 \%$ as effective as the complete package of commercial fertilizers (N, P, K, S, Mg, and micronutrients) (Table 4). Thus, in low-input production systems where supplemental plant nutrients and low quantities of $\mathrm{N}$ and $\mathrm{P}$ fertilizers are used, PBR could be the most cost-effective nutrient source for bioenergy biomass production. The RAE data show that with the addition of $\mathrm{S}, \mathrm{K}, \mathrm{Mg}$

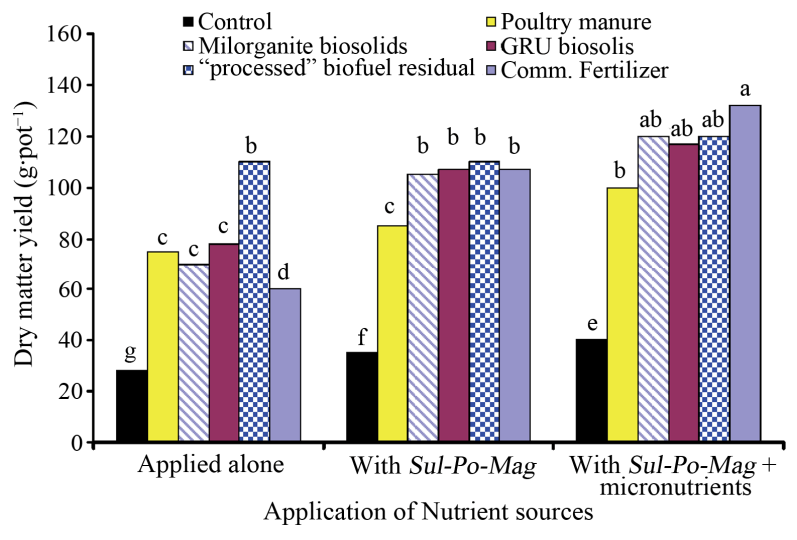

Figure 2. Sweet sorghum dry matter yield as a function of nutrient sources either applied alone or co-applied with micronutrients and/or Sul-Po-Mag (sulfur, potash, and magnesium mixture). Bars with same letters are not significantly different $(P>0.05)$.

Table 4. Relative agronomic efficiency (RAE) of the nutrient sources, and in combination of with micronutrients and Sul-Po-Mag (sulfur, potash and magnesium), used in the study. Treatment means are not significantly different $(P>$ 0.05 ) if followed by same letter.

\begin{tabular}{|c|c|c|c|}
\hline Nutrient sources & Applied alone & $\begin{array}{l}\text { Applied with } \\
\text { Sul-Po-Mag }\end{array}$ & $\begin{array}{c}\text { Applied with } \\
\text { Sul-Po-Mag and } \\
\text { micronutrients }\end{array}$ \\
\hline & \multicolumn{3}{|c|}{$\%$} \\
\hline Inorganic fertilizer & $45.9 \pm 4.32 \mathbf{d}$ & $79.6 \pm 8.12$ bc & $100 \mathbf{a}$ \\
\hline $\begin{array}{c}\text { "Processed" } \\
\text { biofuel residual }\end{array}$ & $85.7 \pm 7.02 \mathbf{b}$ & $86.7 \pm 8.46 \mathbf{b}$ & $91.8 \pm 5.26 \mathbf{b}$ \\
\hline GRU ${ }^{\mathrm{a}}$ biosolids & $53.1 \pm 4.48 \mathbf{d}$ & $79.6 \pm 6.92$ bc & $83.7 \pm 7.23$ bc \\
\hline $\begin{array}{l}\text { Milorganite } \\
\text { biosolids }\end{array}$ & $47.0 \pm 4.52 \mathbf{d}$ & $77.6 \pm 7.23$ bc & $85.6 \pm 8.42$ bc \\
\hline Poultry manure & $50.1 \pm 5.62 \mathbf{d}$ & $70.4 \pm 7.13 \mathrm{c}$ & $73.5 \pm 8.15 \mathrm{c}$ \\
\hline
\end{tabular}

${ }^{\mathrm{a}}$ Gainesville Regional Utilities.

(Sul-Po-Mag) and micronutrients, the organic sources of nutrients, except manure, were $>80 \%$ as effective as commercial fertilizers in biomass production (Table 4).

Several studies have shown that struvite and struvitelike materials can function as slow release fertilizers for environmentally sound crop production $[45,46]$. In greenhouse studies, Yetilmezsoy et al. [46] showed an increase in DMY of Perennial Ryegrass (Lolium perenne) by $>400 \%$, when the plants grown in a "garden soil" received nutrients from struvite-like material obtained by precipitating $\mathrm{N}$ and $\mathrm{P}$ from poultry manure wastewater with $\mathrm{Mg}$. When the material was applied to sandy soils, a DMY increase of $60 \%$ was observed, relative to control treatments, where no nutrients were applied. Other studies have reported an increase in DMY of garden cress (Lepidum sativum) and purslane (Portulaca oleracea) up to $207 \%$ when the grasses were grown on sands, and supplied with nutrients solely from precipitated struvite- 
like material [46]. Plaza et al. [45] reported that struvite from an anaerobic digester supernatant was as effective as inorganic fertilizers in increasing DMY of ryegrass. The DMY data in the present study suggest that in lowinput bioenergy biomass production systems, PBR could be a better nutrient source option than commercial fertilizers, manure, and biosolids. With the current prices of commercial $\mathrm{N}$ fertilizers at $\$ 0.37-0.78 \mathrm{~kg}^{-1}$ (depending on the $\mathrm{N}$ content of the fertilizer type), $\mathrm{P}$ fertilizers at $\$$ $0.65-0.73 \mathrm{~kg}^{-1}$ [47], and Sul-Po-Mag at $0.32 \mathrm{~kg}^{-1}$, application of PBR as a sole nutrient source to grow sweet sorghum could result in a significant reduction in the input cost, if it replaces the required application rates of $150 \mathrm{~kg} \cdot \mathrm{N} \cdot \mathrm{ha}^{-1}, 55 \mathrm{~kg} \cdot \mathrm{P} \cdot \mathrm{ha}^{-1}$, and $225 \mathrm{~kg} \cdot \mathrm{Sul}-\mathrm{Po}-\mathrm{Mag} \cdot \mathrm{ha}^{-1}$.

\subsection{Nitrogen and Phosphorus Uptake and Leaching Losses}

Nitrogen and P uptake followed similar pattern as that of DMY. Across nutrient sources, the greatest $\mathrm{N}$ and $\mathrm{P}$ uptake occurred in the nutrient sources that were applied in combination with $\mathrm{S}, \mathrm{K}, \mathrm{Mg}$, and micronutrients (Table 5). However, for the PBR treatments, there were no significant differences among respective $\mathrm{N}$ and $\mathrm{P}$ uptake of the treatments receiving PBR applied alone, or in combination with micronutrients and/or Sul-Po-Mag (Table 5). This explains the similarity in yield quantities observed for the PBR in the different application strategies (either applied alone or with micronutrient and/or Sul-Po-Mag) (Figure 2).

Applying the organic sources of nutrients based on crop N needs simultaneously supplied $\mathrm{P}$ in excess of the crop requirement. Offsite losses of excess $P$ through runoff and leaching can cause undesirable environmental effects, threatening surface waters bodies with eutrophication when the receiving waters are P-limited [40]. This prompted us to determine potential $\mathrm{P}$ and $\mathrm{N}$ leaching looses following each harvest of the sorghum plants. As pointed out, application of the organic sources of nutri- ents (biosolids, manure, and PBR) at N-based rates resulted in differential total $\mathrm{P}$ application rates (416 g.P.pot ${ }^{-1}$ for PBR; 354 g.P.pot ${ }^{-1}$ for GRU biosolids; 300 g.P.pot ${ }^{-1}$ for Milorganite biosolids; and $240 \mathrm{~g} \cdot \mathrm{P} \cdot \mathrm{pot}^{-1}$ for manure) due to differences in $\mathrm{P}$ content of the organic nutrient sources. Therefore, $\mathrm{P}$ measured in leachate was expressed as a percentage of $\mathrm{P}$ supplied in the nutrient sources. The greatest percent $\mathrm{P}$ leached $(\sim 51 \%)$, occurred within the treatment having the inorganic fertilizers applied alone, with the least occurring in the treatments having Milorganite biosolids and PBR ( 18\%) (Figure 3(a)). Low leachate $P$ concentrations resulting from the Milorganite biosolids was expected because the biosolids is stabilized with $\mathrm{Fe}$ to reduce offsite losses of excess $\mathrm{P}$ [29]. However, without any stabilization with $\mathrm{Fe}$, the PBR material performed as well as the Milorganite biosolids in having reduced $\mathrm{P}$ leaching (Figure 3(a)).

The P leaching data were consistent with the calculated PWEP values of the nutrient sources (Tables 1 and 3 ), and also consistent with the observations of Brandt et al. [22] and Agyin-Birikorang et al. [23] that PWEP values of $\mathrm{P}$ sources were strongly related to off-site $\mathrm{P}$ losses emanating from the P sources. The PBR material in the present study had PWEP value of $\sim 0.2 \%$ (Table 1) and showed the least amount of P leached, followed by Milorganite biosolids (Figure 3(a)), which had a PWEP value of $\sim 0.6 \%$ (Table 3 ). Thus, as suggested by Chinault and O'Connor [13], PWEP could be a priori measure of the offsite $\mathrm{P}$ losses potential of $\mathrm{P}$ sources in vulnerable soils.

Improved $\mathrm{N}$ uptake, through the use of PBR, significantly reduced masses of $\mathrm{N}$ lost to leaching, compared with the other organic sources of nutrients and the inorganic fertilizers (Figure 3(b)) irrespective of whether the nutrient sources were applied alone or in combination with micronutrients and/or Sul-Po-Mag. Supplemental micronutrients and Sul-Po-Mag addition to the nutrient sources (except PBR) improved biomass yields (Figure

Table 5. Nitrogen and phosphorus uptake of sweet sorghum from soil treated with the nutrient sources either applied alone or in combination of with micronutrients and Sul-Po-Mag (sulfur, potash and magnesium).

\begin{tabular}{|c|c|c|c|c|c|c|}
\hline \multirow[b]{2}{*}{ Nutrient sources } & \multicolumn{3}{|c|}{ Nitrogen uptake } & \multicolumn{3}{|c|}{ Phosphorus uptake } \\
\hline & $\begin{array}{l}\text { Applied } \\
\text { alone }\end{array}$ & $\begin{array}{l}\text { Applied with } \\
\text { Sul-Po-Mag }\end{array}$ & $\begin{array}{l}\text { Applied with Sul-Po-Mag } \\
\text { and micronutrients }\end{array}$ & $\begin{array}{l}\text { Applied } \\
\text { alone }\end{array}$ & $\begin{array}{l}\text { Applied with } \\
\text { Sul-Po-Mag }\end{array}$ & $\begin{array}{l}\text { Applied with Sul-Po-Mag } \\
\text { and micronutrients }\end{array}$ \\
\hline & \multicolumn{6}{|c|}{$\mathrm{mg} \cdot \operatorname{pot}^{-1}$} \\
\hline Control & $21.6 \pm 4.26$ & $33.5 \pm 5.62$ & $38.0 \pm 5.88$ & $11.2 \pm 1.26$ & $15.4 \pm 2.07$ & $17.1 \pm 1.98$ \\
\hline Inorganic fertilizer & $96.4 \pm 10.4$ & $168 \pm 17.2$ & $210 \pm 22.3$ & $25.3 \pm 2.65$ & $73.8 \pm 4.96$ & $83.8 \pm 6.34$ \\
\hline "Processed" biofuel residual & $180 \pm 19.6$ & $182 \pm 18.7$ & $193 \pm 20.4$ & $79.8 \pm 9.04$ & $80.3 \pm 10.1$ & $80.6 \pm 10.5$ \\
\hline GRU ${ }^{\mathrm{a}}$ biosolids & $111 \pm 13.2$ & $167 \pm 17.3$ & $176 \pm 19.3$ & $47.6 \pm 4.88$ & $70.5 \pm 8.32$ & $74.1 \pm 8.32$ \\
\hline Milorganite biosolids & $98.6 \pm 10.7$ & $163 \pm 17.6$ & $180 \pm 18.9$ & $35.1 \pm 3.69$ & $68.1 \pm 6.05$ & $72.2 \pm 6.94$ \\
\hline Poultry manure & $105 \pm 11.6$ & $148 \pm 16.1$ & $154 \pm 16.4$ & $30.6 \pm 2.99$ & $62.2 \pm 4.49$ & $64.8 \pm 5.21$ \\
\hline
\end{tabular}

${ }^{\mathrm{a}}$ Gainesville Regional Utility. 


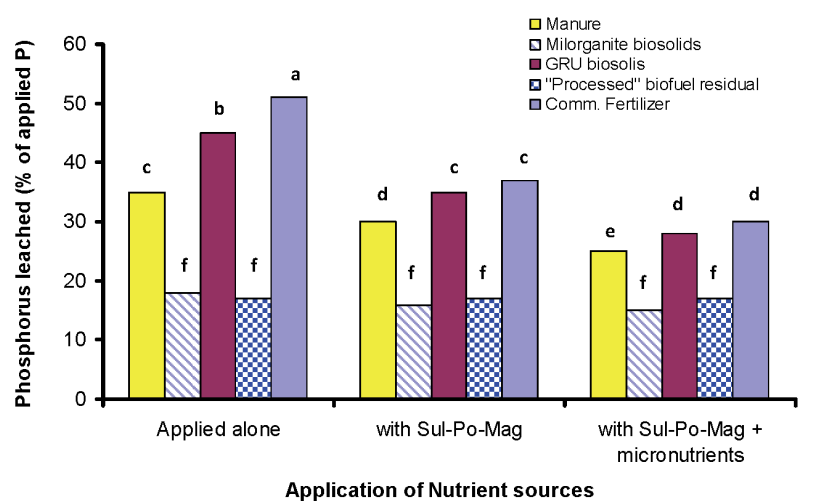

(a)

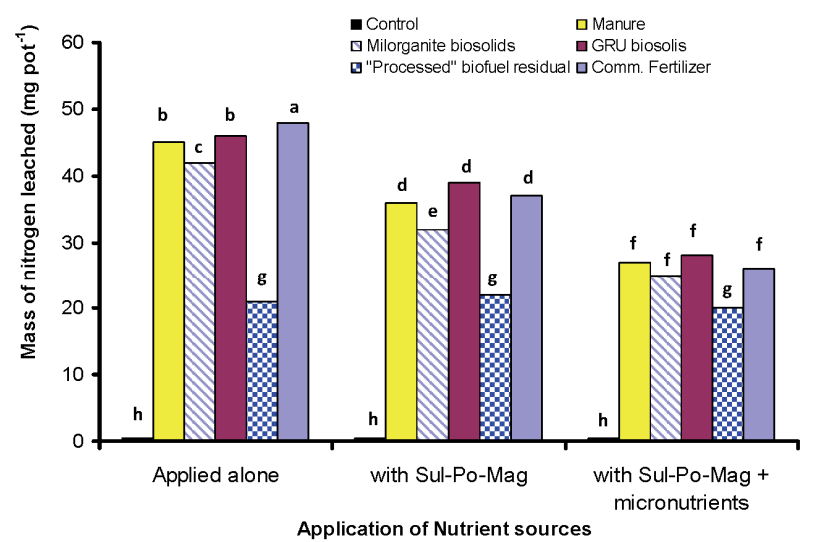

(b)

Figure 3. Percent of applied phosphorus (a) and total nitrogen (b) measured in leachate collected as a function of nutrient sources either applied alone or co-applied with micronutrients and/or Sul-Po-Mag (sulfur, potash, and magnesium mixture). Bars with same letters within a particular (a) or (b) are not significantly different $(P>0.05)$.

2) and consequently, $\mathrm{N}$ and $\mathrm{P}$ uptake (Table 5), resulting in reduced residual soil $\mathrm{N}$ and $\mathrm{P}$ content subject to leaching (Figure 3). The $\mathrm{N}$ and $\mathrm{P}$ leaching losses data suggests that land application of PBR will not only improve biomass yields at reduced cost (no additional $\mathrm{S}, \mathrm{K}, \mathrm{Mg}$, and micronutrients fertilizers application), but could be environmentally friendly, resulting in reduced offsite nutrient losses.

\section{Conclusion}

The chemical characteristics of the PBR examined here suggest that it could be an excellent nutrient source for plant growth, without causing adverse environmental impact when land-applied. This was confirmed in the greenhouse experiments where PBR applied alone was at least $85 \%$ as effective as inorganic $\mathrm{N}$ and $\mathrm{P}$ fertilizers applied together with $\mathrm{S}, \mathrm{K}, \mathrm{Mg}$, and micronutrient, but with minimal $\mathrm{N}$ and $\mathrm{P}$ leaching losses. Thus, the combined data suggest that PBR can be substituted for commercial fertilizers to supply nutrients for biomass pro- duction to reduce production costs (no additional supplemental nutrients required) and to minimize possible discharge of nutrients contained in biofuel residuals to surface water bodies. Utilization of biofuel residuals for biomass production could minimize the indiscriminate disposal of the residuals to landfills. If biofuel residual processing can be exploited in a practical engineering process, there is potential to extract struvite from raw biofuel residual in commercial quantities for slow release $\mathrm{N}$ and $\mathrm{P}$ fertilizer production. The present results were obtained in greenhouse pot experiments, and more research is needed to evaluate the agronomic effectiveness of the PBR in field trials, especially for their long-term effects on soil health, and for other test crops.

\section{Acknowledgements}

This study was funded by State of Florida Federal Stimulus Funds. We wish to express appreciation to Dr. J. E. Erickson of the Agronomy Dept., University of Florida for his collaboration, and to Mr. Richard Fethiere of the Forage Evaluation Support Lab., University of Florida, for his technical assistance in plant tissue analyses.

\section{REFERENCES}

[1] A. Demirbas, "Political, Economic and Environmental Impacts of Biofuels: A Review," Applied Energy, Vol. 86, No. S1, 2009, pp. S108-S117. doi:10.1016/j.apenergy.2009.04.036

[2] S. Kim and B. E. Dale, "Global Potential Bioethanol Production from Wasted Crops and Crop Residues," Biomass and Bioenergy, Vol. 26, No. 4, 2004, pp. 361-375. doi:10.1016/j.biombioe.2003.08.002

[3] P. C. Pullammanappallil, S. A. Svoronos, D. P. Chynoweth and G. Lyberatos, "Expert System for Control of Anaerobic Digesters," Biotechnology and Bioengineering, Vol. 58, No. 1, 1998, pp. 13-22.

doi:10.1002/(SICI)1097-0290(19980405)58:1<13::AID-B IT2>3.0.CO;2-X

[4] S. Gadekar and P. Pullammanappallil, "Validation and Applications of a Chemical Equilibrium Model for Struvite Precipitation," Environmental Modelling and Assessment, Vol. 15, No. 3, 2010, pp. 201-209. doi:10.1007/s10666-009-9193-7

[5] X. Z. Li, Q. L. Zhao and X. D. Hao, "Ammonium Removal from Landfill Leachate by Chemical Precipitation," Waste Management, Vol. 19, No. 6, 1999, pp. 409415. doi:10.1016/S0956-053X(99)00148-8

[6] P. Battistoni, G. Fava, P. Pavan, A. Musacco and F. Cecchi, "Phosphate Removal in Anaerobic Liquors by Struvite Crystallization without Addition of Chemicals: Preliminary Results," Water Research, Vol. 31, No. 11, 1997, pp. 2925-2929. doi:10.1016/S0043-1354(97)00137-1

[7] M. Altinbas, C. Yangin and I. Ozturk, "Struvite Precipitation from Anaerobically Treated Municipal and Landfill Wastewaters," Water Science and Technology, Vol. 46, 
No. 9, 2002, pp. 271-278.

[8] S. Antonini, M. A. Arias, T. Eichert and J. Clemens, "Greenhouse Evaluation and Environmental Impact Assessment of Different Urine-Derived Struvite Fertilizers as Phosphorus Sources for Plants," Chemosphere, Vol. 89, No. 10, 2012, pp. 1202-1210. doi:10.1016/j.chemosphere.2012.07.026

[9] I. Kabdasli, O. Tunay, M. S. Cetin and T. Olmez, "Assessment of Magnesium Ammonium Phosphate Precipitation for the Treatment of Leather Tanning Industry Wastewaters," Water Science and Technology, Vol. 46, No. 4-5, 2002, pp. 231-239.

[10] S. Kalyuzhnyi, V. Sklyar, A. E. L. Arkhipchenko, I. Barboulina, O. Orlova and A. Klapwijk, "Combined Biological and Physico-Chemical Treatment of Filtered Pig Manure Wastewater: Pilot Investigations," Water Science and Technology, Vol. 45, No. 12, 2002, pp. 79-87.

[11] N. O. Nelson, R. L. Mikkelsen and D. L. Hesterberg, "Struvite Precipitation in Anaerobic Swine Lagoon Liquid: Effect of $\mathrm{pH}$ and $\mathrm{Mg}: \mathrm{P}$ Ratio and Determination of Rate Constant," Bioresource Technology, Vol. 89, No. 9, 2003, pp. 229-236. doi:10.1016/S0960-8524(03)00076-2

[12] G. E. Diwani, S. E. Rafie, N. N. E. Ibiari and H. I. ElAila, "Recovery of Ammonia Nitrogen from Industrial Wastewater Treatment as Struvite Slow Releasing Fertilizer," Desalination, Vol. 214, No. 1-3, 2007, pp. 200-214. doi:10.1016/j.desal.2006.08.019

[13] K. Yetilmezsoy and Z. Sapci-Zengin, "Recovery of Ammonium Nitrogen from the Effluent of UASB Treating Poultry Manure Wastewater by MAP Precipitation as a Slow Release Fertilizer," Journal of Hazardous Materials, Vol. 166, No. 1, 2009, pp. 60-269. doi:10.1016/i.jhazmat.2008.11.025

[14] J. M. Andersen, “An Ignition Method for Determination of Total Phosphorus in Lake Sediments," Water Research, Vol. 10, No. 4, 1976, pp. 329-331.

[15] A. Mehlich, "Mehlich-3 Soil Test Extractant: A Modification of Mehlich-2 Extractant," Communications in Soil Science and Plant Analysis, Vol. 15, No. 12, 1984, 14091416. doi:10.1080/00103628409367568

[16] W. H. Gardner, "Water Content," In: A. Klute, Ed., Methods of Soil Analysis, Part 1, ASA Monograph, 9, American Society of Agronomy, Madison, 1986, pp. 493-545.

[17] G. W. Thomas, "Soil pH and Soil Acidity," In: D. L. Sparks, Ed., Methods of Soil Analysis, Part 3, SSSA Book Series, 5, Soil Science Society of America, Madison, 1996, pp. 475-490.

[18] J. M. Bremmer, "Determination of Nitrogen in Soil by the Kjeldahl Method," Journal of Agricultural Science, Vol. 55 , No. 1, 1960, pp. 11-33. doi:10.1017/S0021859600021572

[19] D. R. Keeney and D. W. Nelson, "Nitrogen-Inorganic Forms," In: A. L. Page, Ed., Methods of Soil Analysis, Part 2, ASA Monograph, 9, 2nd Edition, American Society of Agronomy, Madison, 1982, pp. 498-523.

[20] E. Florence and D. F. Milner, "Routine Determination of Nitrogen by Kjeldahl Digestion without Use of Catalyst,"
Analyst, Vol. 104, No. 1237, 1979, pp. 378-381. doi:10.1039/an9790400378

[21] J. D. Beaton, G. R. Burns and J. Platou, "Determination of Sulfur in Soils and Plant Materials," Tech Bull. No. 14, Sulfur Institute, Washington DC, 1968.

[22] R. C. Brandt, H. A. Elliott and G. A. O'Connor, "Water Extractable Phosphorus in Biosolids: Implications for Land-Based Recycling," Water Environment Research, Vol. 76, No. 2, 2004, pp. 121-129. doi:10.2175/106143004X141645

[23] S. Agyin-Birikorang, G. A. O'Connor and S. R. Brinton, "Evaluating Phosphorus Loss from a Florida Spodosol as Affected by P-Source Application Methods," Journal of Environmental Quality, Vol. 37, No. 3, 2008, pp. 11801189. doi: $10.2134 /$ jeq2007.0535

[24] P. R. Day, "Particle Fractionation and Particle-Size Analysis," In: C. A. Black, D. D. Evans and R. C. Dinauer, Eds., Methods of Soil Analysis, Part 1, ASA Monograph, 9, American Society of Agronomy, Madison, 1965, pp. 545-567.

[25] E. O. McLean, "Soil pH and Lime Requirement," In: A. L. Page, Ed., Methods of Soil Analysis, Part 2, ASA Monograph, 9, 2nd Edition, American Society of Agronomy, Madison, 1982, pp. 199-224.

[26] D. W. Nelson and L. E. Sommers, "Total Carbon, Organic Carbon, and Organic Matter,” In: D. L. Sparks, Ed., Methods of Soil Analysis, Part 3, SSSA Book Series, 5, Soil Science Society of America, Madison, 1996, pp. 961-1010.

[27] S. Kuo, "Phosphorus," In: D. L. Sparks, Ed., Methods of Soil Analysis, Part 3, ASA Monograph, 5, American Society of Agronomy, Madison, 1996, pp. 869-919.

[28] R. Mylavarapu, D. Wright, G. Kidder and C. G. Chambliss, "UF/IFAS Standardized Fertilization Recommendations for Agronomic Crops," Coop. Ext. Serv. IFAS, University of Florida, SL129, 2007.

http://edis.ifas.ufl.edu/SS163

[29] S. L. Chinault and G. A. O'Connor, "Phosphorus Release from a Biosolids-Amended Sandy Spodosol," Journal of Environmental Quality, Vol. 37, No. 3, 2008, pp. 937-943. doi:10.2134/jeq2007.0139

[30] A. S. Bennett and R. P. Anex, "Farm-Gate Production Costs of Sweet Sorghum as a Bioethanol Feedstock," Transactions of the ASABE, Vol. 56, No. 2, 2008, pp. 603-613.

[31] A. Monti and G. Venturi, "Comparison of the Energy Performance of Fibre Sorghum, Sweet Sorghum and Wheat Monocultures in Northern Italy," European Journal of Agronomy, Vol. 19, No. 1, 2003, pp. 35-43. doi:10.1016/S1161-0301(02)00017-5

[32] J. Murphy and J. P. Riley, “A Modified Single Solution Method for the Determination of Phosphate in Natural Waters," Analytica Chimica Acta, Vol. 26, No. 1, 1962, pp. 31-36. doi:10.1016/S0003-2670(00)88444-5

[33] R. N. Gallaher, C. O. Weldon and J. G. Futral, "An Aluminum Block Digester for Plant and Soil Analysis," Soil Science Society of America Journal, Vol. 39, No. 4, 1975 , pp. 803-806. 
doi:10.2136/sssaj1975.03615995003900040052x

[34] S. H. Chien, R. G. Menon and K. S. Billingham, "Estimation of Phosphorus Availability to Maize and Cowpea from Phosphate Rock as Enhanced by Water-Soluble Phosphorus," Soil Science Society of America Journal, Vol. 60, No. 4, 1996, pp. 81173-1177.

doi:10.2136/sssaj1996.03615995006000040031x

[35] United States Environmental Protection Agency, "Methods for Chemical Analysis of Water and Wastes," EPA600/4-79-020, USEPA, Washington DC, 1983.

[36] SAS Institute, "SAS Online Documentation," Version 9.1.3, SAS Institute, Cary, 2002.

[37] R. C. Littell, G. A. Milliken, W. W. Stroup and R. D. Wolfinger, "SAS System for Mixed Models," SAS Institute, Cary, 1996.

[38] G. E. P. Box and D. R. Cox, "An Analysis of Transformations," Journal of the Royal Statistical Society Series B: Statistical Methodology, Vol. 26, No. 2, 1964, 211-243.

[39] N. C. Brady and R. R. Weil, "The Nature and Properties of Soil," 14th Edition, Prentice Hall, Upper Saddle River, 2007.

[40] H. A. Elliott, G. A. O'Connor and S. Brinton, "Phosphorus Leaching from Biosolids-Amended Sandy Soils," Journal of Environmental Quality, Vol. 32, No. 2, 2002, pp. 681-689. doi:10.2134/jeq2002.0681

[41] P. Jain, J. Yong-Chul, T. Thabet, M. Witwer and T. Townsend, "Recycling of Water Treatment Plant Sludge via Land Application: Assessment of Risk," Journal of Residuals Science and Technology, Vol. 2, No. 2, 2005, pp.
13-23.

[42] United States Environmental Protection Agency, "Process design Manual: Land Application of Sewage Sludge and Domestic Septage," EPA/625/R-95/001, Office of Research and Development, Cincinnati, 1995.

[43] G. A. O'Connor and H. A. Elliott, "The Agronomic and Environmental Availability of Biosolids-P (Phase II)," Rep. 99-PUM-2T Water Environment Research Foundation, Alexandria.

[44] H. A. Elliott, R. C. Brandt and G. A. O'Connor, "Runoff Phosphorus Losses from Surface-Applied Biosolids," Journal of Environmental Quality, Vol. 34, No. 5, 2005, pp. 1632-1639. doi: $10.2134 /$ jeq2004.0467

[45] C. Plaza, R. Sanz, C. Clemente, J. M. Fernandez, R. Gonzalez and A. Polo, "Greenhouse Evaluation of Struvite and Sludges from Municipal Wastewater Treatment Works as Phosphorus Sources for Plants," Journal of Food, Agriculture and Environment, Vol. 55, No. 20, 2007, pp. 8206-8212. doi:10.1021/if071563y

[46] K. Yetilmezsoy, B. Sertyesilisik, E. Kocak and Z. SapciZengin, "Ameliorative Effect of Different Doses of $\mathrm{Mg}$ $\mathrm{NH}_{4} \mathrm{PO}_{4} \cdot 6 \mathrm{H}_{2} \mathrm{O}$ Precipitate Recovered from the Effluent of UASB Treating Poultry Manure Wastewater: Growth of Lolium perenne," Journal of Food, Agriculture and Environment, Vol. 7, No. 3-4, 2009, pp. 823-831.

[47] United States Department of Agricultures, "Fertilizer Use and Price," 2012.

http://www.ers.usda.gov/data-products/fertilizer-use-andprice.aspx 